Original Article

\section{Prevalence and outcome of teenage pregnancy among attendants of labour room in Bassion general hospital-Egypt (cross section study)}

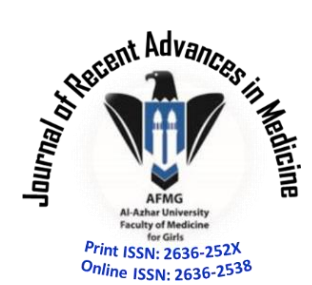

Online ISSN: $2636-2538$

Obstetrics and Gynecology

Salma A. Eldaboly ${ }^{1}$, Nahed E. Allam ${ }^{1}$, Mervat M. Ibrahiem ${ }^{1}$, Hanaa A. Abo-Elhssan ${ }^{2}$

${ }^{1}$ Obstetrics and gynecology Department, Faculty of Medicine for Girls, Cairo, Al-Azhar University, Egypt

${ }^{2}$ Public health and Community Medicine Department, Faculty of Medicine for Girls, Cairo, Al-Azhar University, Egypt.

\title{
ABSTRACT
}

Background: Teenage pregnancy is a global serious public health and distressing social problem, its prevalence varies among countries and among cities of the same country. Teenage mothers are exposed to maternal morbidity and mortality than women in their twenties.

Objective: to assess prevalence of teenage pregnancy and their perinatal outcomes \& immediate postpartum complications.

Methodology: A cross -sectional study was conducted at a hospital that provides medical services to a rural area in Egypt, for six months period, started from $1^{\text {st }}$ December 2019 till $1^{\text {st }}$ June 2020. All women consecutively recruited were either full or preterm, singleton or multiple pregnancy. They were admitted in active labour at the delivery ward of Bassion general hospital. All demographic, prenatal and postnatal data during study period were recorded and tabulated.

Results: All pregnant women who were admitted in active labour within the chosen period were 848 women, $73.6 \%$ were adults ( $>19$ years, mean 24.06years), $26.4 \%$ were teenagers ( $\leq 19$ years, with a mean 17.5 years). Iron deficiency anemia was the most prevalent medical complication in the teenage group 54\%, followed by pregnancy induced hypertension (PIH) $21.4 \%$, caesarean section rate was $47 \%$ and perineal tears were recorded in $25.9 \%$ of the teenage group. Most of them had $2^{\text {nd }}$ and $3^{\text {rd }}$ degree tears. $25.9 \%$ of the newborns were admitted to the neonatal intensive care unit (NICU), $4.9 \%$ due to prematurity, $4.5 \%$ due to prematurity and respiratory distress (RDs) and sepsis, $3.6 \%$ due to prematurity and RD, $1.3 \%$ due to $\mathrm{RD}, 04 \%$ due to meconium aspiration, $4.5 \%$ due to hyperbillirubinemia and $3.1 \%$ due to cyanosis.

Conclusion: Teenage pregnancy is prevalent in this study sample in a rural area in Egypt and is associated with an increased risk of major degree perineal tear, PIH, preterm labour and iron deficiency anemia.

JRAM 2021: 2(2): 166-172

Key words: Perineal tear, preterm labour, teenage pregnancy

Submission Date: 5 December 2020

Acceptance Date: 12 January 2021

Corresponding author: Salma A. Eldaboly, obstetrics and gynecology department, faculty of medicine for Girls, Cairo, Al-

Azhar University, Egypt, Tel: 01066080672. E-mail: salmaabdelwahab050@gmail.com

Please cite this article as: Salma A. Eldaboly SA, Allam NE, Ibrahiem MM, Abo Elhssan HA. Prevalence and outcome of teenage pregnancy among attendants of labour room in Bassion general hospital-Egypt (cross section study). JRAM 2021: 2(2): 166-172. DOI: 10.21608/jram.2021.50943.1100

\section{INTRODUCTION}

Adolescent pregnancy is defined as the occurrence of pregnancy in girls aged $10-19$ years. Almost one-tenth of all births are to women below 20 years old, and more than $90 \%$ of such births occur in developing countries. It is most likely affected by multifactorial conditions like socioeconomic, demographic, and cultural problems ${ }^{[1]}$. In Egypt Abbas et al. ${ }^{[2]}$ reported in his study in Egyptian women, that the incidence of teenage pregnancy is $17 \%$ and most cases are from the rural area.
Three years before Al-Haddabi et al. ${ }^{[3]}$ reported a quite similar range of $16-18 \%$. This target group expected to be according to statistical results $44 \%$ in 2030 according to the Egypt Demographic Health Survey 2014, it was reported that one in six girls begins childbearing by the time of their $18^{\text {th }}$ birthday ${ }^{[4]}$. It is estimated that 70,000 pregnant teenagers die each year due to physical immaturity ${ }^{[5]}$. The aim of this study is to assess prevalence of teenage pregnancy and their intra-partum and immediate postpartum complications in Bassion general hospital, Al-Gharbia, Egypt. 


\section{PATIENTS AND METHODS}

A cross -sectional study was conducted at Bassion General Hospital which is the only governmental hospital at Bassion city and covers the health services for 17 nearby villages. Bassion city is $1230 \mathrm{~km} 2$, and its population estimate 306,012 according to last census in July 2019.The study done during six months period started from $1^{\text {st }}$ December 2019 till 1st June 2020.

Study population inclusion criteria: all women had full or preterm, singleton or multiple pregnancy, were admitted in active labour at delivery wards of Bassion general hospital.

Sample size justification: at delivery ward of Bassion hospital, about 8 women admitted for delivery each day. The expected average admission 6 and expected recruitment period $24 \mathrm{ws}$. The sample size was calculated according to previous data with adjustment of power to $80 \%$, and confidence interval of $95 \%$, sampling method: consecutive sampling (non-probability sample).

The study protocol was approved by the research ethics committee, Al-Azhar university faculty of medicine, Cairo, Egypt. Informed verbal consents were obtained from all recruited women before participation in this study. The nature and aim of this work were fully discussed with all women. No funding resources. All participants subjected to detailed history taking (personal, present and past history), general physical examination and Obstetric examination and ultrasound examination if needed. Following outcomes recorded in spread data sheet: Maternal and neonatal mortalities, mode of delivery, intra--partum, and postpartum complications up to 24 hours, neonatal outcome as birth weight, Apgar score at 5minutes, neonatal intensive care unit (NICU) admission and its indication.

\section{Statistical analysis}

statistical analyses of data carried out using SPSS version 23. Shapiro -Wilks's test was used to test normal distribution of variables. Numerical data were expressed as mean \pm standard deviation or median and range. Categorical data were summarized as numbers and percentages. The significance for the difference between groups determined by using two-tailed Student $t$ test and one way ANOVA (analysis of variance) test or for quantitative data as appropriate. Also, Qualitative variables were assessed by chi-squared $\chi 2$ test. P-value $<0.05$ was considered significant. Moreover, correlations between maternal age and various data were evaluated using Pearson and spearman correlation coefficient as appropriate.

\section{RESULTS}

All pregnant women who were admitted in active labour at ward within chosen period were $624(73.6 \%)$ adults who aged $>19$ years with a mean age 24 years and 224 $(26.4 \%)$ were teenage ( $\leq 19$ years) with a mean age 17.5 years (table1). $37.5 \%$ of teenage women were illiterate, $0 \%$ reach university level and all of them were housewives which is statistically different from the adult group (table 2). Most of teenage women were primis (54.9\%) and $45.1 \%$ had previous pregnancies (full term, preterm, miscarriage) which is statistically different from the adult group (table 3 ).

Anemia was found in 54\% of teenagers which is statistically more than the adult group, $1.3 \%$ of teenagers had DM which is less than the adult group, PIH was found in $21.4 \%$ which is statistically different from the adult group (table 3). Ante-partum hemorrhage was recorded in $2.7 \%$ of teenagers with no statistically difference between the 2 groups. $14.3 \%$ ) of the teenagers coming in labour before 34 weeks gestation (preterm) which is statistically found more than the adult group. The C.S rate was $43.3 \%$ among teenagers, $78.3 \%$ of them were emergency and showing statistically significant difference with the adult group. Vaginal delivery rate was $56.7 \%$ among teenagers, $58.3 \%$ of them with episiotomy which was significantly less than the adult group.

Regarding perineal tears, they were less statistically found in the teenage group $(25.9 \%)$ had perineal tears and 2 patients $(0.9 \%)$ had rupture uterus. $7.6 \%$ of teenagers needed blood transfusion $2.7 \%$ due to antepartum hemorrhage, $3.1 \%$ due to postpartum hemorrhage and $1.8 \%$ due to emergency CS. $2.2 \%$ of teenage postpartum hemorrhage were atonic and $0.8 \%$ were traumatic with no significant difference between them and the adult group (table 4). $4 \%$ of teenage women had surgical exploration under general anesthesia, $0.9 \%$ of them were laparotomy and $3.1 \%$ vaginal exploration due to perineal tears repair. $18.8 \%$ of teenage women were admitted in the hospital more than 24 hours and it was statistically more than the adult group (table 4). Mean neonatal birth weight among teenagers was $2.9 \mathrm{~kg}$ versus $3.3 \mathrm{~kg}$ in adult group with $\mathrm{p}$ value $0.002,25.9 \%$ of newborns were admitted to NICU, $4.9 \%$ due to prematurity, $4.5 \%$ due to prematurity with $\mathrm{RD}$ and sepsis, $3.6 \%$ due to prematurity with $\mathrm{RD}, 1.3 \%$ due to $\mathrm{RD}, 4 \%$ due to meconium aspiration, $4.5 \%$ due to hyperbillirubinemia and $3.1 \%$ due to cyanosis (table 5). 
Table (1): Age data among all attendants

\begin{tabular}{|c|c|}
\hline Age (years) & \\
\hline Mean \pm SD & $24.06 \pm 5.43$ \\
\hline Min.-max. & $14-44$ \\
\hline $\begin{array}{c}\text { Age groups }(\mathbf{n}=\mathbf{8 4 8}) \\
\text { - Teenage }(\leq 19 \text { years }) \\
\text { - Adult }(>19 \text { years })\end{array}$ & $\begin{array}{l}224(26.4 \%) \\
624(73.6 \%)\end{array}$ \\
\hline
\end{tabular}

Table (2): Educational level and Occupation among the studied sample

\begin{tabular}{|c|c|c|c|}
\hline Educational level and occupation & $\begin{array}{c}\text { Teenage females } \\
\begin{array}{c}(\mathbf{n}=224) \\
n(\%)\end{array}\end{array}$ & $\begin{array}{l}\text { Adult females } \\
\qquad \begin{array}{c}\text { (n-624) } \\
\text { n }(\%)\end{array}\end{array}$ & $P$ value \\
\hline $\begin{array}{l}\text { Education level: } \\
\text { - Illiterate } \\
\text { - Primary/preparatory } \\
\text { - Secondary } \\
\text { - University }\end{array}$ & $\begin{array}{c}84(37.5 \%) \\
105(46.9 \%) \\
35(15.6 \%) \\
0(0.0 \%)\end{array}$ & $\begin{array}{l}105(16.8 \%) \\
194(31.1 \%) \\
234(37.5 \%) \\
91(14.6 \%)\end{array}$ & $0.000 *$ \\
\hline $\begin{array}{l}\text { Occupation: } \\
\text { - House wife } \\
\text { - Working }\end{array}$ & $\begin{array}{c}224(100 \%) \\
0(0.0 \%)\end{array}$ & $\begin{array}{l}555(88.9 \%) \\
69(11.1 \%)\end{array}$ & $0.000 *$ \\
\hline
\end{tabular}

Table (3): Antenatal data among the studied sample

\begin{tabular}{|c|c|c|c|}
\hline Groups & $\begin{array}{c}\text { Teenage females } \\
\begin{array}{c}(\mathrm{n}=224) \\
\mathbf{n}(\%)\end{array}\end{array}$ & $\begin{array}{l}\text { Adult females } \\
\qquad \begin{array}{c}\text { (n-624) } \\
\text { n }(\%)\end{array}\end{array}$ & $P$ value \\
\hline $\begin{array}{l}\text { Parity: } \\
\text { - Zero } \\
\text { - One } \\
\text { - Two } \\
\text {-Three or more } \\
\text { Mean } \pm \text { SD }\end{array}$ & $\begin{array}{c}123(54.9 \%) \\
87(38.8 \%) \\
13(5.8 \%) \\
1(0.4 \%) \\
0.51 \pm 0.62\end{array}$ & $\begin{array}{l}59(9.4 \%) \\
76(12.2 \%) \\
217(34.7 \%) \\
272(42.7 \%) \\
2.21 \pm 1.08\end{array}$ & $0.001^{*}$ \\
\hline $\begin{array}{l}\text { Associated medical conditions: } \\
\text { - No } \\
\text { - Anemia } \\
\text { - PIH } \\
\text { - Diabetes Mellitus }\end{array}$ & $\begin{array}{c}52(23.2 \%) \\
121(54.0 \%) \\
48(21.4 \%) \\
3(1.3 \%)\end{array}$ & $\begin{array}{l}351(56.2 \%) \\
183(29.3 \%) \\
51(8.2 \%) \\
39(6.2 \%)\end{array}$ & $0.001 *$ \\
\hline $\begin{array}{l}\text { Associated obstetric conditions: } \\
\text { - Placenta Previa } \\
\text { - Abruptio Placentae }\end{array}$ & $\begin{array}{l}2(0.9 \%) \\
4(1.8 \%)\end{array}$ & $\begin{array}{l}8(1.3 \%) \\
3(0.5 \%)\end{array}$ & 0.161 \\
\hline $\begin{array}{l}\text { Antenatal care: } \\
\text { - Yes } \\
\text { - No }\end{array}$ & $\begin{array}{c}162(72.3 \%) \\
62(27.7 \%)\end{array}$ & $\begin{array}{l}455(72.9 \%) \\
169(27.1 \%)\end{array}$ & 0.864 \\
\hline $\begin{array}{l}\text { Gestational age/weeks: } \\
\text { Mean } \pm \text { SD } \\
\text { Premature } \\
\text { Full term }\end{array}$ & $\begin{array}{c}38.15 \pm 1.61 \\
32(14.3 \%) \\
192(85.7 \%)\end{array}$ & $\begin{array}{c}38.86 \pm 1.29 \\
27(4.3 \%) \\
597(95.7 \%)\end{array}$ & $\begin{array}{l}0.001 * \\
0.001 *\end{array}$ \\
\hline
\end{tabular}


Table (4): Post-natal data among the studied sample

\begin{tabular}{|c|c|c|c|}
\hline $\begin{array}{ll}\text { Post-Natal data } & \text { Groups }\end{array}$ & $\begin{array}{c}\text { Teenage females } \\
(\mathbf{n = 2 2 4 )} \\
\mathbf{n}(\%)\end{array}$ & $\begin{array}{l}\text { Adult females } \\
\begin{array}{c}\text { (n-624) } \\
\text { n }(\%)\end{array}\end{array}$ & $P$ value \\
\hline $\begin{array}{l}\text { Post- partum complications: } \\
\quad \text { - Yes } \\
\quad \text { - No } \\
\text { Atonic postpartum hemorrhage } \\
\text { Traumatic postpartum hemorrhage }\end{array}$ & $\begin{array}{c}7(3.1 \%) \\
217(96.9 \%) \\
5(2.2 \%) \\
2(.8 \%)\end{array}$ & $\begin{array}{c}13(2.1 \%) \\
611(97.9 \%) \\
11(1.7 \%) \\
2(.3 \%)\end{array}$ & 0.378 \\
\hline $\begin{array}{l}\text { Hospital stay/ days: } \\
\text { - One day(24hours) } \\
\text { - More than one day }\end{array}$ & $\begin{array}{l}182(81.2 \%) \\
42(18.8 \%)\end{array}$ & $\begin{array}{l}555(88.9 \%) \\
69(11.1 \%)\end{array}$ & $0.003^{*}$ \\
\hline Duration $($ mean \pm SD) & $1.44 \pm 1.05$ & $1.23 \pm 0.81$ & $0.002 *$ \\
\hline
\end{tabular}

Table (5): neonatal outcomes among the studied sample:

\begin{tabular}{|c|c|c|c|}
\hline Outcome data & $\begin{array}{c}\text { Teenage females } \\
\qquad \begin{array}{c}(n=224) \\
n(\%)\end{array}\end{array}$ & $\begin{array}{c}\text { Adult females } \\
\begin{array}{c}\text { (n-624) } \\
\text { n }(\%)\end{array}\end{array}$ & P value \\
\hline $\begin{array}{l}\text { NICU admission: } \\
\text { - Yes } \\
\text { - No }\end{array}$ & $\begin{array}{c}58(25.9 \%) \\
166(74.1 \%)\end{array}$ & $\begin{array}{c}76(12.2 \%) \\
548(87.8 \%)\end{array}$ & $0.000^{*}$ \\
\hline Birth weight/gms (mean \pm SD) & $2899.1 \pm 504.9$ & $3267.47 \pm 465.4$ & $0.000^{*}$ \\
\hline APGAR Score 5 min. (mean \pm SD) & $8.49 \pm 0.90$ & $8.64 \pm 0.79$ & $0.022 *$ \\
\hline $\begin{array}{l}\text { IUGR: } \\
\text { - Yes } \\
\text { - No }\end{array}$ & $\begin{array}{c}7(3.1 \%) \\
217(96.9 \%)\end{array}$ & $\begin{array}{c}15(2.4 \%) \\
609(97.6 \%)\end{array}$ & 0.560 \\
\hline
\end{tabular}

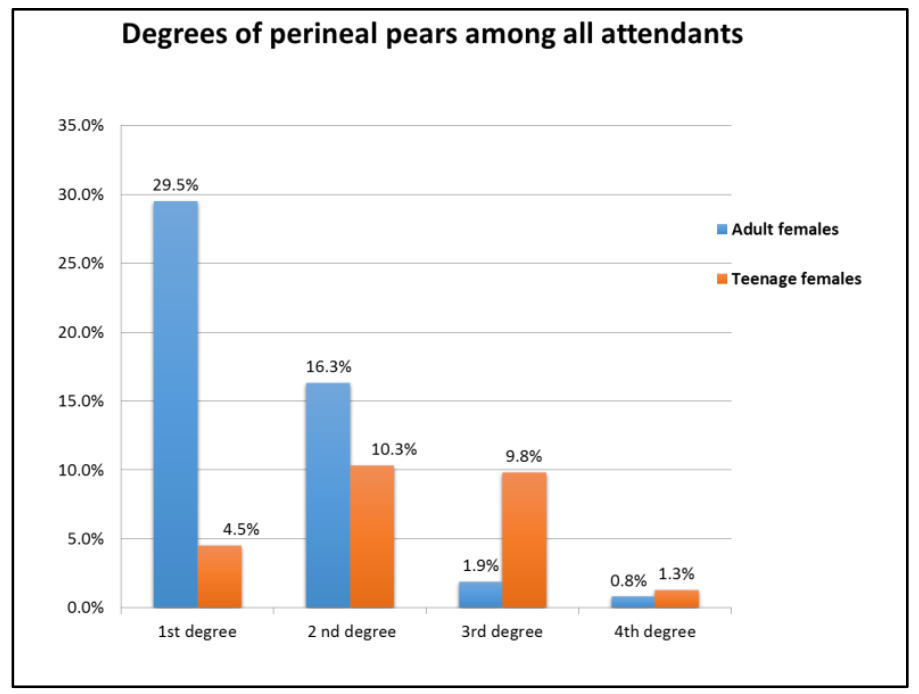

Figure (1): Degree of perineal tears among all attendant 


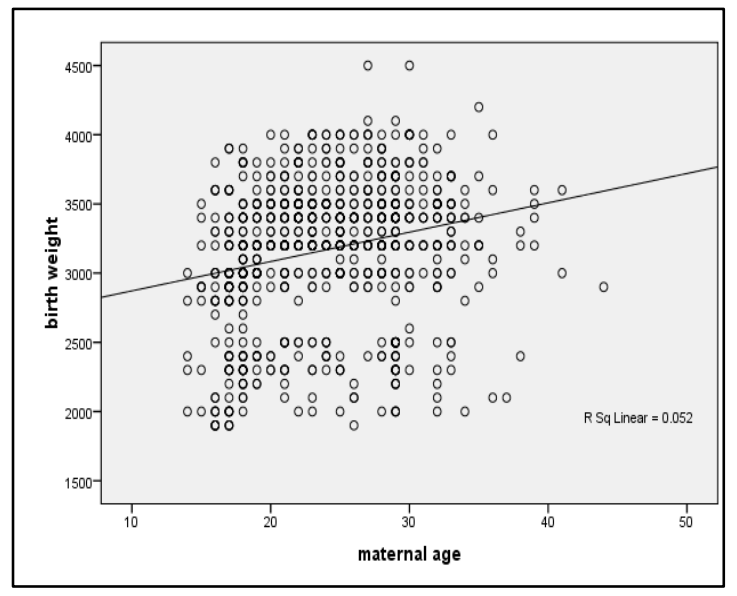

Figure (2): Correlation of maternal age with birth weight

\section{DISCUSSION}

Teenage pregnancy is a significant problem across the world. It has become an important health issue in Africa and whole developing countries. Its importance originated from its impact on health of young individuals, it is considered as major cause of mortality and morbidity among girls. During 6 month period and place scale of a hospital providing medical services to a rural area in Egypt, it was found that among all cases admitted for delivery teenage women were prevalent in one quarter of this sample, it looks higher than that reported by previous reports like Abbas et al. ${ }^{[2]}$ in different region in upper Egypt (Assiut Woman's Health Hospital). ${ }^{[2]}$ They reported $17 \%$ incidence of teenage pregnancy also in 6 months duration. All literature show that the prevalence of teenage pregnancy varies across regions of the world even varies widely among different divisions in the same country. The variation of prevalence among countries could be attributed to the difference in civilization between urban and rural population as regard culture, availability of services and education levels.

Lack of education is one of risk factors that lead to teenage pregnancy. Like most of literature who reported that drop out of education drive teenage girls for marriage and pregnancy, the current study reported illiteracy among teenager was more than one third, around one half of them (46.9\%) stopped at primary and preparatory schools and no cases completed the university education. Although most of teenage women have antenatal registration card but unfortunately the visits usually scarce and irregular.

Maternal anemia is the most common health problem encountered, more than half of the enrolled teenage cases were anemic (HB level $<10.5 \mathrm{gm} l \mathrm{dl}$ ). As we know the intensity of growth in adolescent period necessitates the increase in nutritional needs. During this period there is a high demand for iron, especially in the adolescent girl because of the onset of menstruation, so risk for anemia increases when the adolescent girl becomes pregnant. In agreement with our results, many studies have shown that pregnant adolescents may have significantly higher rates of anemia compared with adult pregnant women ${ }^{[6]}$. Appropriate ANC program could solve this problem, but it could be compromised by incompliant patient and deficient resources.

The younger the maternal age the higher the risk of hypertensive disorder associated with pregnancy, in this study, PIH was found to be significantly associated with adolescent mothers. This finding agreed with previous studies. In agreement with the present, Kumar et al., $2007^{[7]}$; Rasheed et al. ${ }^{[8]}$ reported that adolescence is a risk factor for preeclampsia and eclampsia. However, some studies with retrospective data found no significant difference in the risk of pregnancy-induced-hypertension (PIH) between adolescent and adult mothers ${ }^{[9],[10],[11]}$.

Teenage pregnancy significantly associated with increased rate preterm births and significant positive correlation between maternal age and neonatal birth weight which are consistent with various literatures $[12],[13],[14]$. The mechanism of preterm labor among teenage mothers is still under investigated. In accordance to our results Ogawa et al., ${ }^{[14]}$ found that adolescent women have increased risks for neonatal adverse outcomes such as preterm birth, low birth weight, and low Apgar score, they proposed that the increased risk of adverse neonatal outcomes among adolescent women were partially mediated by shorter maternal height, suggesting a role for maternal physical immaturity, also another physiological reason is immaturity of the uterine and cervical blood supply in young mothers which leads to increase in prostaglandin production leading to preterm labor .The birth weight babies in teenage mothers was significantly lower in comparison to the adult mothers, due to higher rate of preterm labour among them. Also, higher incidence of NICU admission rate. This observation corroborates with various other literatures ${ }^{[13]}$. This study reported increased rate cesarean section among teenage mothers most of them of category 1and 2 CS but elective CS less needed and its only indication was repeated CS. This increased emergency cesarean delivery in This study attributed to 
higher rate of pregnancy induced hypertension and prematurity. The mode of delivery of adolescent mothers is thoroughly investigated and the data is somewhat inconsistent. Adolescent mothers tend to have lower rates of elective cesarean deliveries and higher rates of normal vaginal deliveries as reported by Abbas et al. ${ }^{[5]}$.

Although perineal tears less encountered in teenage group but most of them were major degree tear also post partum hemorrhage and rupture uterus were significantly found more in teenage group that leads to prolonged hospital stay and increased need for blood transfusion in teenage group. These traumatic complications could be due to biological immaturity as reported in previous literatures, and due to delayed referral to hospital.

Limitation encountered is that due to COVID-19 pandemic, study sample size was less than expected. Recommendation for increasing sample size in future studies. One more limitation is the socioeconomic status an important multifaceted confounding factor in teenage pregnancy complication not well investigated in our study due to limited information.

Increased awareness, enhancement of educational program, maternity care strategies and the improvement of health education programs suggested to reduce adverse pregnancy outcomes among teenage mothers in developing countries.

\section{CONCLUSIONS}

Teenage pregnancy is quite prevalent in this study sample as an example of tertiary hospital serving rural areas in Egypt and is associated with adverse obstetric outcome. Teenage pregnant women prone to develop preterm births, PIH, anemia and their newborns at increased risk of NICU admission and prematurity. Lack of education and awareness are main contributing factors. Appropriate maternal care strategies should be considered.

Financial support: No financial support.

Conflict of interest: No conflict of interest.

\section{REFERENCES}

1. Kassa GM, Arowojolu AO, Odukogbe AA, and Yalew AW. Prevalence and determinants of adolescent pregnancy in Africa: a systematic review and meta-analysis. Reproductive health, 2018 Dec 1;15(1):195-211.

2. Abbas AM, Ali SS, Ali MK, Fouly H, and Altraigey A (2017). The maternal and neonatal outcomes of teenage pregnancy in a tertiary university hospital in Egypt. Proceedings in Obstetrics and Gynecology, 2017; 7(3):1-10.

3. Al-Haddabi R, Al-Bash M, Al-Mabaihsi N, AlMaqbali N, Al-Dhughaishi T, and AbuHeija A.
Obstetric and perinatal outcomes of teenage pregnant women attending a tertiary teaching hospital in oman. Oman Medical Journal, 2014; 29(6):399-403.

4. Mohamed NA and Mahmoud GA. Self-concept and self-esteem among adolescent pregnant women at general Assiut hospital, Assiut City. Egyptian Nursing Journal, 2018;1;15(2):93-101.

5. Yasmin G, Kumar A, and Parihar B. Teenage pregnancy-its impact on maternal and fetal outcome. International journal of scientific study, 2014; 1(6):9-

6. Jusoh N, Ismail TA, and Daud A. Anemia among teenage pregnancy in Northwestern Malaysia: What are the factors? International Journal of Collaborative Research on Internal Medicine and Public Health, 2015; 7(12):196-206.

7. Kumar A, Singh T, Basu S, Pandey S, and Bhargava V. Outcome of teenage pregnancy. Indian journal of pediatrics, 2007; 74(10):927-931.

8. Rasheed S, Abdelmonem A, and Amin $M$. Adolescent pregnancy in Upper Egypt. The International Journal of Gynecology and Obstetrics, 2011; 112(1):21-24.

9. Karabulut A, Ozkan S, Bozkurt AI, Karahan T, and Kayan S. Perinatal outcomes and risk factors in adolescent and advanced age pregnancies: Comparison with normal reproductive age women. Journal of Obstetrics and Gynaecology, 2013; 33(4):346-350.

10. Chantrapanichkul $P$ and Chawanpaiboon $S$ (2013). Adverse pregnancy outcomes in cases involving extremely young maternal age. International Journal of Obstetrics and Gynaecology, 2013; 120(2):160-4.

11. Bildircin FD, Kurtoglu E, Kokcu A, Isik Y, Ozkarci M, and Kuruoglu S. Comparison of perinatal outcome between adolescent and adult pregnancies. Journal of Maternal, Fetal and Neonatal Medicine, 2014; 27(8):829-832.

12. Olausson PO, Cnattingius $S$, and Haglund $B$. Does the increased risk of preterm delivery in teenagers persist in pregnancies after the teenage period? British Journal of Obstetrics and Gynaecology, 2001; 108(7):721-725.

13. Kawakita T, Wilson K, Grantz KL, Landy HJ, Huang CC, and Gomez-Lobo V. Adverse maternal and neonatal outcomes in adolescent pregnancy. Journal of pediatric and adolescent gynecology, 2016; 29(2):130-136.

14. Ogawa K, Matsushima S, Urayama KY, Kikuchi $\mathbf{N}$, Nakamura N, Tanigaki S, et al. Association between adolescent pregnancy and adverse birth outcomes, a multicenter cross sectional Japanese study. Scientific reports, 2019, 9(1):1-8. 


\section{الماخدص العربي \\ معدل انتشار الحمل و نواتجه بين السيدات دون سن التاسعة عشر عاما بمستشفى بسيون العام

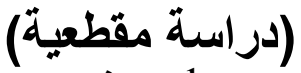

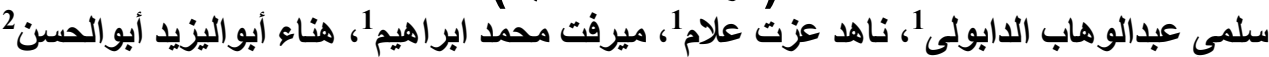

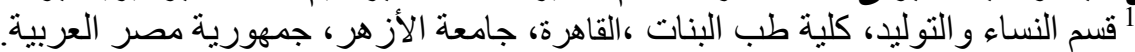

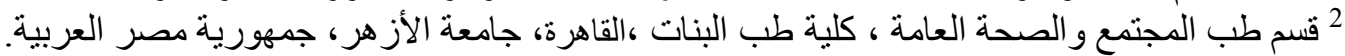

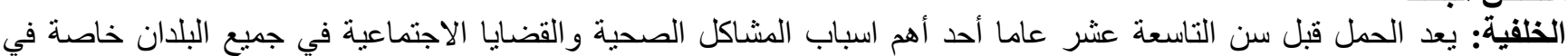

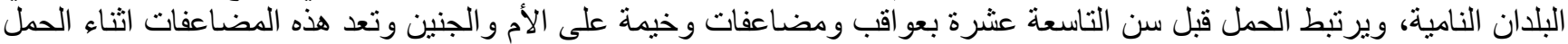

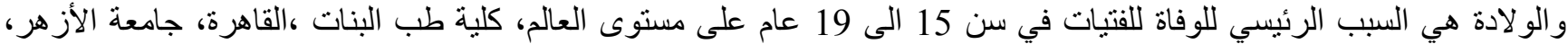

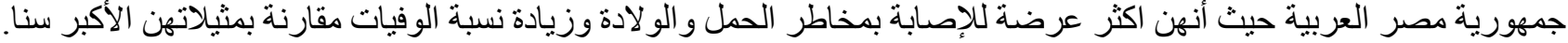

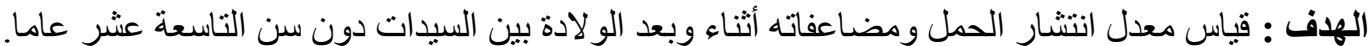

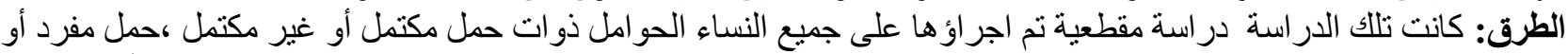

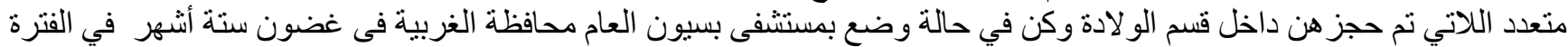

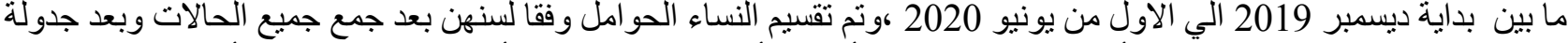

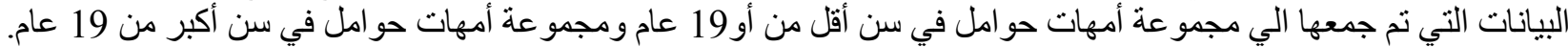

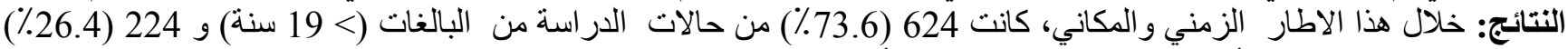

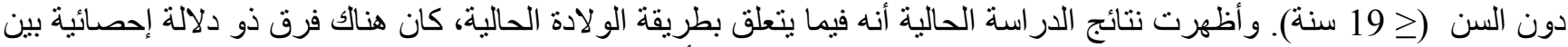

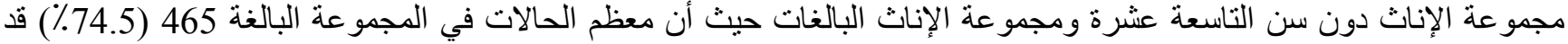

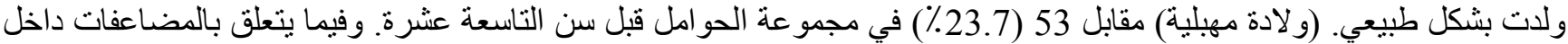

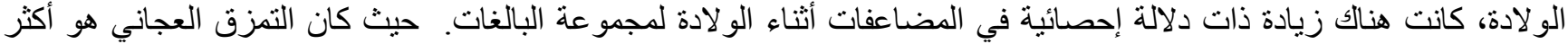

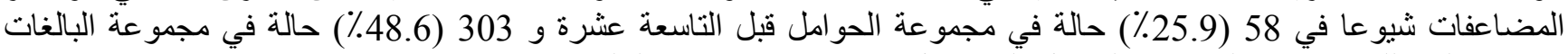

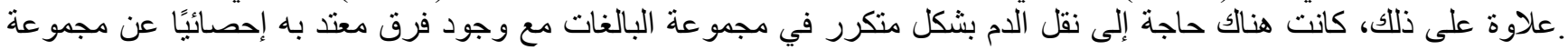

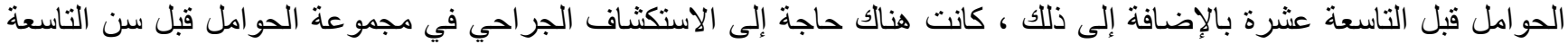

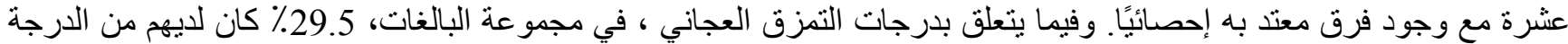

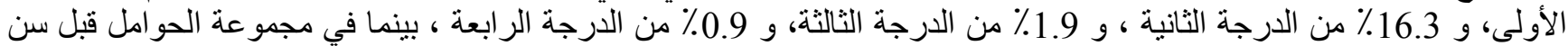

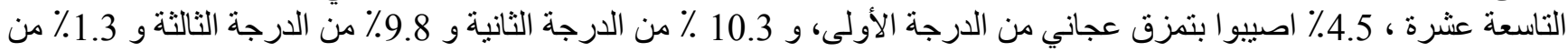

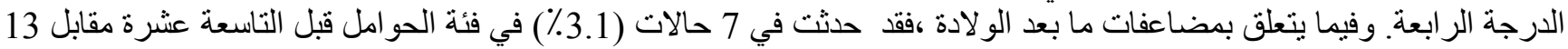

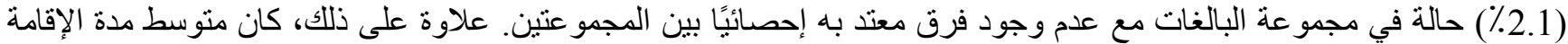

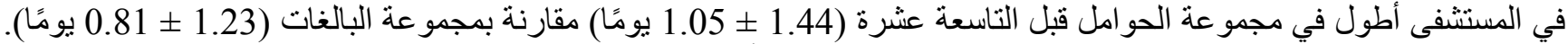

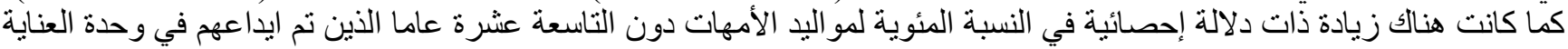

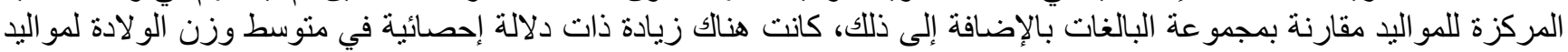

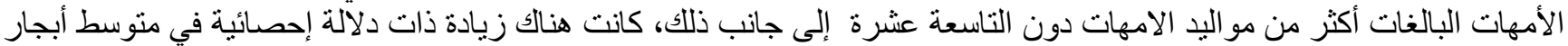

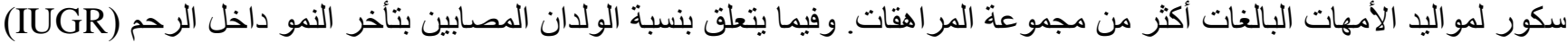

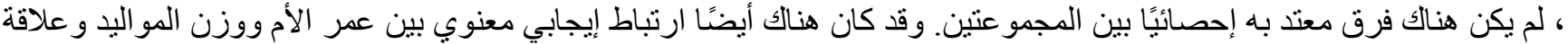

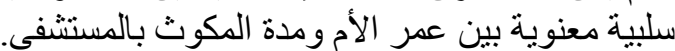

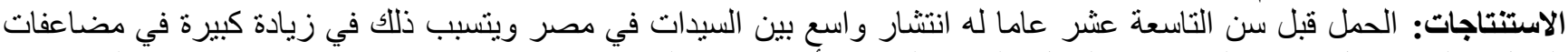
الحمل و الو لادة مثل ارتفاع الضغط مع الحمل، الو لادة المبكرة، أنيميا نقص الحديد و تمزق عجانى ذو درجات خطيرة اثناء الو لادة. الكلمات المفتاحية: تمزق عجانى، حمل قبل سن التاسعة عشرة، و لادة مبكرة.

الباحث الرئيسي:

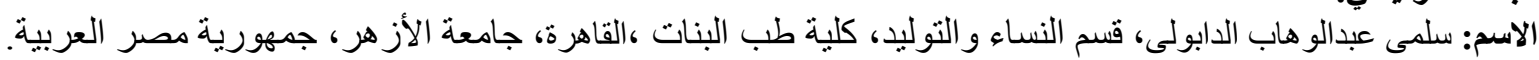
الهاتف: 2066080672 البريد الإكتروني:gmail.com 